SLNs were processed with an ultrastaging technique. Between 26 June 2014 and 31 December 2019 with 333 patients we applied the previous treatment algorithms. Between January and 30 August 2021 we did only SNL in 45 patients.

Result(s)* Comparation of the results between the ancient and the new serie (ancient/new): Detection rate 94\%/97.7\% overall for SLNs; 91.3\%/97.7\% overall for pelvic SLNs; 70.5\%/88.8\% for bilateral SLNs; $68.1 \% / 88.8 \%$ for paraaortic SLNs, and $2.9 \% / 0 \%$ for isolated paraaortic SLNs. Macrometastasis $18 \% / 6 \%$ patients and microdisease $17.6 \% /$ $8.8 \%$ patients, overall rate of $\mathrm{LN}$ involvement $16.2 \% / 11 \%$. Isolated Aortic metastases 4.2\%/2.2\% (14/333-1/45). Assuming the results of the ancient serie there was one false/negative (negative SLN with positive lymphadenectomy). Our sensitivity of detection was 98.3\% (95\% CI 91-99.7), specificity $100 \%$ (95\% CI 98.5-100), negative predictive value 99.6\% (95\% CI 97.8-99.9), and positive predictive value 100\% (95\% CI 93.8-100).

Conclusion* SLN biopsy is an acceptable alternative to systematic lymphadenectomy for LN staging in stage $\mathrm{I} / \mathrm{II}$. We avoid 22/45 (48.8\%) lymphadenectomies with new algorithm, reducing the morbidity in our patients. Our surgical times were shorter improving our theaters efficiency with all that implies for. Additionally, this technique allows a high rate of aortic detection, identifying a non-negligible percentage of isolated aortic metastases. Isolated Aortic metastases in endometrial cancer are possible and we should not give up actively looking for them.

\section{THE IMPACT OF SENTINEL LYMPH NODE BIOPSY ALONE ON SURVIVAL OF PATIENTS WITH ENDOMETRIAL CANCER (TRSGO-SLN-007)}

${ }^{1} \mathrm{D}$ Altõn*, ${ }^{2} \mathrm{~S}$ Taşkın, ${ }^{3} \mathrm{~N}$ Tokgözoğlu, ${ }^{4} \mathrm{D}$ Vatansever, ${ }^{5} \mathrm{AH}$ Güler, ${ }^{6} \mathrm{M}$ Gungor, ${ }^{7} \mathrm{~T}$ Taşçı, ${ }^{8} \mathrm{H}$ Turan, ${ }^{9} \mathrm{I}$ Kahramanoglu, ${ }^{10} \mathrm{i}$ Yalçın, ${ }^{5} \mathrm{C}$ Celik, ${ }^{6} \mathrm{~F}$ Köse, ${ }^{2} \mathrm{FU}$ Ortac, ${ }^{11} \mathrm{M}$ Arvas, ${ }^{12} \mathrm{~A}$ Ayhan, ${ }^{4} \mathrm{C}$ Taskiran. ${ }^{1}$ Ordu Üniversitesi Eğitim ve Araştırma Hastanesi, Turkey; ${ }^{2}$ Ankara Üniversitesi Tıp Fakültesi, Turkey; ${ }^{3}$ Prof. Dr. Cemil Taşcıoğlu Șehir Hastanesi, Turkey; ${ }^{4}$ Koc University, Turkey; ${ }^{5}$ Selçuk Üniversitesi Tip Fakültesi, Turkey; ${ }^{6}$ Acıbadem University School of Medicine, Turkey; 'Bahçessehir Üniversite Hastanesi Medical Park Göztepe, Turkey; ${ }^{8} T$ C Saglik Bakanligi Istanbul Egitim ve Arastirma Hastanesi, Turkey; ${ }^{9}$ Emsey Hastanesi, Turkey; ${ }^{10}$ Ondokuz Mayıs University, Turkey; ${ }^{11}$ Cerrahpaşa Tip Fakültesi, Turkey; ${ }^{12}$ Başkent Üniversitesi Tip Fakültesi, Turkey

\subsection{6/ijgc-2021-ESG0.653}

Introduction/Background* Diagnostic efficacy of sentinel lymph node (SLN) biopsy is proven in many studies in terms of the detection of lymphatic spread in endometrial cancer. However, there are limited data about the effect of SLN biopsy only on survival. The aim of this study was to investigate whether SLN biopsy only compromises oncologic outcomes compared to systematic lymphadenectomy in a large cohort.

Methodology In this multicentric study, records of 564 endometrial cancer patients who underwent surgical staging with either sentinel lymph node biopsy alone or sentinel lymph node biopsy followed by systematic lymphadenectomy with at least 6 months of follow-up time were retrospectively reviewed. The impact of type of lymphadenectomy and histopathologic factors on recurrence, disease-free survival (DFS) and overall survival (OS) were assessed. DFS and OS rates were calculated using Kaplan-Meier method and log- rank test was used to calculate statistical significance between the groups. Cox univariate and multivariate analyses were used to identify prognostic factors for DFS and OS.

Result(s)* Median follow up time was 28 months (range: 6$130)$ and $14(2.5 \%)$ of the $21(3.7 \%)$ deaths were due to the disease. 2- and 3-year OS were 98.2\% and 97\%, respectively. Median time to recurrence was 12.5 months (range: 3-30). Sites of the $42(7.4 \%)$ recurrences were as follows: 12 (28.6\%) locoregional, 19 (45.2\%) distant, 3 (7.1\%) nodal and 8 (19\%) more than one site. 2- and 3-year DFS were 93.1\% and 92.6\%, respectively. While non-endometrioid subtypes $(p=0.048)$, grade 3 histology $(p<0.001)$ and presence of lymphovascular space invasion (LVSI) $(\mathrm{p}<0.001)$ were found as independent prognostic factors for decreased DFS, age $(\mathrm{p}=0.017)$ and tumor size $(\mathrm{p}=0.041)$ were independent factors for shorter OS. Type of lymphadenectomy was not a prognostic factor lymphatic recurrence, DFS and OS.

Conclusion* Our study showed that removal of only SLNs was not associated with worse survival compared to systematic lymphadenectomy in endometrial cancer patients. Nodal recurrence rate was also similar between the groups.

\section{FERTILITY PRESERVATION IN ENDOMETRIAL CANCER: PERINATAL AND ONCOLOGIC OUTCOMES}

V García Pineda*, M Turiel, M Gracia, I Zapardiel, MD Diestro, J Siegrist, Y Pérez Martínez, A Hernández. La Paz University Hospital, Gynaecological Oncology, Madrid, Spain

\subsection{6/ijgc-2021-ESG0.654}

Introduction/Background* The aim of our study is to evaluate the oncological and perinatal outcomes in young women diagnosed with atypical endometrial hyperplasia (AH) or endometrial cancer (EC) treated with hormone therapy.

Methodology A single institutional ambispective study was performed including all patients diagnosed with $\mathrm{AH}$ or EC grade 1 without myometrial invasion who received hormone therapy between January 2011 and July 2021. We analyzed the complete response rate and recurrence rate of disease and pregnancy rate in these patients as well as perinatal results (live births rate, type of delivery and perinatal morbidity). In addition, we evaluated complete response rate according to type of hormone therapy, dosage received and treatment length.

A review of literature was performed to identify studies involving patients with $\mathrm{AH}$ or $\mathrm{EC}$ who received fertility sparing management.

All statistical analysis were performed using the software SPSS Statistics v.24.0 (IBM Corp., Armonk, NY, USA).

Result(s)* There were 6 patients with AH/EC (4 and 2 patients respectively) who received hormone therapy with a mean treatment time of $8.6 \pm 1.96$ months. Hormone therapy with megestrol acetate was carried out in 4 patients $(66.6 \%)$. Complete remission was achieved in 5 patients $(83.3 \%)$ and 2 of them $(33.3 \%)$ attempted pregnancy. Finally, no complications during pregnancy were reported in this 2 patients and both had normal delivery. The rate of live birth was $33.3 \%$. During the follow-up no recurrences were detected and overall survival was $100 \%$

Conclusion* Conservative management with progestins of young patients with $\mathrm{AH}$ or EC grade 1 limited to the endometrium is an acceptable possibility given the high remission 
rate and live birth rates achieved. However, definitive surgical treatment cannot be avoided given the high recurrence rate described in the literature.

\section{IMPLEMENTATION OF THE SENTINEL NODE TECHNIQUE FOR ENDOMETRIAL CANCER IN BELGIUM: A MULTICENTRIC RETROSPECTIVE STUDY FROM 2015 TO 2020}

\begin{abstract}
${ }^{1 ;}{ }^{2} \mathrm{M}$ Luyckx ${ }^{*},{ }^{3} \mathrm{M}$ Fastrez, ${ }^{4} \mathrm{~F}$ Goffin, ${ }^{5} \mathrm{M}$ Jouret, ${ }^{6} \mathrm{Z}$ Al Abkadri, ${ }^{6} \mathrm{~T}$ Willems, ${ }^{7} \mathrm{~F}$ Buxant, ${ }^{8} \mathrm{D}$ Buccella, ${ }^{9} \mathrm{M}$ De Cuypere, ${ }^{9} \mathrm{~A}$ Kakkos, ${ }^{9} \mathrm{~F}$ Kridelka, ${ }^{10} \mathrm{~L}$ Debuyl, ${ }^{10} \mathrm{~B}$ Vandermeersch, ${ }^{11} \mathrm{~K}$ Crener, ${ }^{12} \mathrm{~N}$ Dubois, ${ }^{12} \mathrm{JP}$ Van Gossum, ${ }^{13} \mathrm{~F}$ Grandjean, ${ }^{14} \mathrm{~V}$ Malvaux, ${ }^{14} \mathrm{JC}$ Lousse, 1J Squifflet. 'Cliniques universitaires Saint-Luc (UCLouvain), Gynecology and Andrology, Bruxelles, Belgium; ' ${ }^{2}$ e Duve Institute UCLouvain, TIL's group, Woluwe-Saint-Lambert, Belgium; ${ }^{3}$ Hospital Erasme, gynecology and obstetrics, Bruxelles, Belgium; ${ }^{4} \mathrm{CHR}$ de la Citadelle, gynecology and obstetrics, Liège, Belgium; ${ }^{5}$ Centre Hospitalier de Wallonie picarde (CHwapi), gynecology and obstetric, Tournai, Belgium; ${ }^{6}$ Grand Hôpital De Charleroi - Notre Dame, gynecology and obstetrics, Charleroi, Belgium; ${ }^{7}$ Hôpital Etterbeek-Ixelles/Ziekenhuis Etterbeek-Elsene, gynecology and obstetrics, Ixelles, Belgium; ${ }^{8} \mathrm{CHU}$ Saint-Pierre, gynecology and obstetrics, Bruxelles, Belgium; ${ }^{9}$ Hospital Center Universitaire De Liege, Site N.-D. Des Bruyères, gynecology and obstetrics, Liège, Belgium; ${ }^{10}$ Clinique Sainte-Anne Saint-Rémi, gynecology and obstetrics, Anderlecht, Belgium; ${ }^{11}$ Chu Ambroise Paré, gynecology and obstetrics, Mons, Belgium; ${ }^{12}$ Clinique Saint Jean, gynecology and obstetrics, Bruxelles, Belgium; ${ }^{13}$ Europe Hospitals - St-Michel Site, gynecology and obstetrics, Etterbeek, Belgium; ${ }^{14}$ Saint-Pierre Ottignies Clinic, gynecology and obstetrics, Ottignies-Louvain-la-Neuve, Belgium
\end{abstract}

\subsection{6/ijgc-2021-ESG0.655}

Introduction/Background* Sentinel node is a very powerful tool in endometrial cancer, giving information on nodal status involvement, with low morbidity. Within a few years, it became part of the standard treatment, at least for low and intermediate-risk patients. Its implementation, safety and reliability, and the evolution of the patient have to be monitored to confirm its great added value and its place in the standard of care for endometrial cancer

Methodology We performed a multicenter retrospective review of all endometrial cancer cases in which SN procedures (with/ without pelvic and paraaortic lymphadenectomy) was planned to be performed, from the centers of the gynecological oncology group (ONCO-GF) of the Gynecology and Obstetrics association, french speaking part in Belgium (CR-GOLFB). Academic and non-academic hospitals participate. The study was accepted by the Ethical Committee of the coordinating center of the study (Cliniques Universitaires St Luc) and registered on clinicltrial.gov (NCT02545348).

Result(s)* To date, 233 patients were included in the study but some center have still to send a part of their data. Preliminary data show that $96 \%$ of the surgery we performed by minimally invasive approach. Overall detection rate is $90 \%$ but only $69 \%$ of bilateral detection. Regarding the tracer, the best bilateral detection rate was obtained with Indocyanine green (84\%). With the methylene blue alone, no detection occurs in $22 \%$ of cases. In a preliminary pathological analysis of the sentinel node, $17 \%$ of SN were infiltrated, $8 \%$ with macro metastasis, $2 \%$ of micro metastasis, and $8 \%$ isolated tumor cells (ITC). We did not record any major intraoperative complication, but one late post-operative dead, in a patient with complete pelvic and para-aortic lymphadenectomy with a duodenal breach that leads to late aorticduodenal fistula.

Conclusion* Our preliminary data show a very good detection rate of $96 \%$, even if bilateral detection was only $69 \%$, in a group of patients from academic and non-academic centers. Learning curves and the evolution of the patient must still be evaluated. The complete data will be presented at the congress.

\section{A RANDOMISED PHASE II STUDY OF COMBINATION CHEMOTHERAPY WITH NINTEDANIB/PLACEBO IN ADVANCED/RECURRENT ENDOMETRIAL CANCER. FANDANGO/ENGOT-EN1/FANDANGO}

\begin{abstract}
${ }^{1} \mathrm{M}$ Mirza, ${ }^{2} \mathrm{D}$ Berton, ${ }^{3}$ I Vergote, ${ }^{4} \mathrm{R}$ Depont Christensen, ${ }^{5} \mathrm{~A}$ Floquet, ${ }^{6} \mathrm{~J}$ Maenpaa, ${ }^{7} \mathrm{~B}$ Braicu, ${ }^{8} \mathrm{~S}$ Altintas, ${ }^{9} \mathrm{P}$ Follana, ${ }^{10} \mathrm{~A}$ Ør Knudsen, ${ }^{11} \mathrm{~B}$ Ataseven, ${ }^{12} \mathrm{~F}$ Selle, ${ }^{13} \mathrm{C}$ Lundgren, ${ }^{14} \mathrm{~J}$ Huober, ${ }^{15} \mathrm{M}$ Fabbro, ${ }^{16} \mathrm{H}$ Denys, ${ }^{17} \mathrm{P}$ Heudel, ${ }^{4} \mathrm{M}$ Magnusson, ${ }^{18} \mathrm{~K}$ Lindemann, ${ }^{7} \mathrm{~J}$ Sehouli. ${ }^{1}$ Rigshospitaletd, Denmark; ${ }^{2}$ GINECO: Groupe d'Investigateurs National des Etudes des Cancers Ovariens et du sein and ICO Centre René Gauducheau, Saint-Herblain, France; ${ }^{3} B G O G$ : Belgium and Luxembourg Gynaecological Oncology Group and Universitaire Ziekenhuizen Leuven, , Belgium; ${ }^{4}$ NSGO-CTU; ${ }^{5}$ GINECO: Groupe d'Investigateurs National des Etudes des Cancers Ovariens et du sein and Institut Bergonié, Bordeaux, France; ${ }^{6}$ Tampere University Hospital, Finland; ${ }^{7}$ Charité, Germany; ${ }^{8}$ BGOG: Belgium and Luxembourg Gynaecological Oncology Group and Antwerp University Hospital, Belgium; ${ }^{9}$ GINECO: Groupe d'Investigateurs National des Etudes des Cancers Ovariens et du sein and Centre Antoine Lacassagne Nice, France; ${ }^{10}$ NSGO-CTU: Nordic Society of Gynaecological Oncology - Clinical Trial Unit and University Hospital Odense, Denmark; ${ }^{11}$ NOGGO: Northeast German Society of Gynaecological Oncology and Kliniken Essen Mitte, , Germany; ${ }^{12}$ GINECO: Groupe d'Investigateurs National des Etudes des Cancers Ovariens et du sein and Groupe Hospitalier Diaconesses, Paris, France; ${ }^{13}$ NSGO-CTU: Nordic Society of Gynaecological Oncology - Clinical Trial Unit and Karolinska University Hospital, Stockholm, Sweden; ${ }^{14}$ NOGGO: Northeast German Society of Gynaecological Oncology and University Hospital Ulm, Germany; ${ }^{15}$ GINECO: Groupe d'Investigateurs National des Etudes des Cancers Ovariens et du sein and ICM Val d'Aurelle, Montpellier, France; ${ }^{16} B G O G$ : Belgium and Luxembourg Gynaecological Oncology Group and Gent University Hospital, Belgium; ${ }^{17}$ GINECO: Groupe d'Investigateurs National des Etudes des Cancers Ovariens et du sein and Centre Léon Bérard, Lyon; ${ }^{18}$ Oslo university hospital, Norway
\end{abstract}

\subsection{6/ijgc-2021-ESG0.656}

Introduction/Background* Endometrial cancer (EC) patients (Pts) with advanced and recurrent disease relapse despite treatment with combination chemotherapy and have a short progression-free survival (PFS). Nintedanib $(\mathrm{N})$ is a potent, orally available triple receptor tyrosine kinase inhibitor targeting VEGFR 1-3, PDGFR $\alpha / \beta$, and FGFR 1-3. This study explored the preliminary efficacy of nintedanib in EC.

Methodology The primary objective of this placebo-controlled, randomized study was to evaluate efficacy defined by median PFS of concomitant and maintenance $\mathrm{N}$ against placebo $(\mathrm{P})$ in combination with chemotherapy. Patients with histologically confirmed stage IIIC2 or IVA \& B or relapsed after adjuvant therapy for stage I-III disease; prior surgery; adjuvant chemotherapy; radiation therapy; hormonal therapy in metastatic setting; with measurable/non-measurable disease were permitted. Pts were randomized $1: 1$ to receive $\mathrm{N} 200 \mathrm{mg}$ or $\mathrm{P}$, twice daily days 2-21 during chemotherapy (six cycles of Carboplatin (AUC5) and paclitaxel $(175 \mathrm{mg} / \mathrm{m} 2)$ every 21 days) and continuously in maintenance phase. $\mathrm{N} / \mathrm{P}$ was continued until disease progression, unacceptable toxicity, or withdrawal of consent. Stratification by stage of disease, prior adjuvant chemotherapy and measurable/non-measurable disease. This is an ENGOT Model A study. Clinical trial information: NCT02730416.

Result(s)* 146 of 148 pts were eligible for PFS: 72N/74P; mean age 66yrs; FIGO stage III 18\%, IV 42\%, recurrent 40\%; follow-up 30 mo. $\mathrm{N}$ added to chemotherapy did not improve PFS (119 events) as compared to chemotherapy plus 